\title{
MOLICUTES E VÍRUS EM MILHO NA SAFRINHA E NA SAFRA DE VERÃO
}

\author{
ELIZABETH DE OLIVEIRA ${ }^{1}$, ROBERTO VENCESLAU DE CARVALHO ${ }^{2}$, AILDSON PEREIRA \\ DUARTE ${ }^{3}$, ROGÉRIO ALVARES DE ANDRADE ${ }^{4}$, RENATO DE OLIVEIRA RESENDE ${ }^{5}$, CHARLES \\ MARTINS DE OLIVEIRA ${ }^{1}$, PAULO CÉSAR RECCO ${ }^{2}$.
}

\author{
${ }^{1}$ Pesquisadores Embrapa Milho e Sorgo. Caixa Postal 151, CEP.35701-970 Sete Lagoas, MG. E-mail: \\ beth@cnpms.embrapa.br (autor para correspondência). \\ ${ }^{2}$ Sementes Dow AgroScience. Caixa Postal 47, CEP.14680-000 Jardinópolis, SP. \\ ${ }^{3}$ IAC/CDV. Caixa Postal 263, CEP.19800-000 Assis, SP. \\ ${ }^{4}$ Monsanto. Caixa Postal 94, CEP.75920-000 Santa Helena de Goiás, GO. \\ ${ }^{5}$ UNB - Departamento de Biologia Celular. CEP.70910-900 Brasília, DF.
}

Revista Brasileira de Milho e Sorgo, v.1, n.2, p.38-46, 2002

\begin{abstract}
RESUMO - A incidência de plantas de milho com sintomas de enfezamentos causados por molicutes ou de infecção por vírus foi avaliada em um ensaio com 22 cultivares, plantadas na safrinha e na safra de verão, em diferentes locais nos estados de São Paulo, Goiás e Minas Gerais. Essas avaliações foram feitas a partir da safrinha de 1999 até a safrinha de 2001. Amostras de folhas com sintomas de enfezamentos foram submetidas à extração de DNA e ao teste de PCR, para determinação dos índices de infecção por fitoplasma e por espiroplasma. Amostras de folhas com sintomas de viroses foram submetidas a testes RT-PCR, para confirmação da identificação do vírus. Em geral, a incidência de sintomas de enfezamentos foi maior na safrinha que na safra de verão, exceto no Estado de São Paulo, onde a incidência dessas doenças foi semelhante nas duas épocas de cultivo. A infecção por molicutes foi detectada em 103 amostras, dentre 390 submetidas ao teste de PCR. A infecção simultânea por espiroplasma e por fitoplasma foi detectada em apenas seis dessas amostras. Considerandose o total de amostras positivas quanto à infecção por molicutes, os níveis de incidência de espiroplasma e de fitoplasma foram semelhantes. Contudo, na safrinha, observou-se que apenas um desses molicutes predominou. Essa predominância foi alternada de espiroplasma na safrinha de 1999, para fitoplasma na safrinha 2000 e espiroplasma na safrinha de 2001 . O Maize Rayado Fino Virus (MRFV) e o Maize Dwarf Mosaic Virus (MDMV) foram detectados em níveis de incidência variáveis, apenas em alguns locais e safras avaliados, em geral, com níveis de incidência inferiores aos níveis de incidência dos enfezamentos.
\end{abstract}

Palavras-chave: Espiroplasma, fitoplasma, MRFV, MDMV, Zea mays.

\section{MOLLICUTES AND VIRUSES ON MAIZE AT THE "SAFRINHA" GROWING SEASON AND AT THE "SUMMER" GROWINGSEASON.}

\begin{abstract}
The incidence of Corn stunt diseases symptoms and virus infection symptoms was surveyed on 22 cultivars sowed in the "Safrinha" growing season and in the "Summer" growing season at several localities in São Paulo, Goiás and Minas Gerais States. These survey was made from Safrinha 1999 until Safrinha 2000. Leaves samples from plants with Corn stunt diseases symptoms were submitted to DNA extraction and to PCR test to determine the incidence index of infection by phytoplasma and by spiroplasma. Leaves samples with virus infection symptoms were submitted to RT-PCR to confirm the virus identification. In general,
\end{abstract}


the incidence of Corn stunt diseases symptoms was higher in the Safrinha growing season than in the Summer growing season, except in São Paulo state where the incidence of these diseases was similar on both seasons. The mollicute infection was detected in 103 samples, among 390 submitted to PCR test. The simultaneous infection by both spiroplasma and phytoplama was detected only in 6 samples. Taken into account the total of positive samples to mollicute infection, the incidence of spiroplasma and phytoplasma was similar. However, only in the Safrinha growing season it was observed that only one of these mollicute predominated. This predominance alternated from spiroplasma in Safrinha 1999, to phytoplasma in Safrinha 2000 and spiroplasma in Safrinha 2001. The Maize Rayado Fino Virus (MRFV) and the Maize Dwarf Mosaic Virus (MDMV) were detected in variable levels of incidence, just at some localities and growing season evaluated, in general with incidence levels lower than the ones of Corn stunt diseases.

Key-words: Spiroplasma, phytoplasma, MRFV, MDMV, Zea mays.

Desde a década de 80, os plantios de milho de segunda época, ou safrinha, por constituírem uma opção rentável para o período de outono, têm aumentado e atingem atualmente 2,4 milhões de hectares em área plantada, representando $15 \%$ da produção nacional de milho (Conab, 2001).

Esses plantios de safrinha proporcionam a sobreposição de ciclos da cultura, o que tem sido apontado como causa principal da alta incidência e severidade de doenças no milho (Fernandes \& Oliveira, 1997). A sobreposição de ciclos das plantas favorece a sobrevivência de patógenos e de insetos vetores de molicutes e de vírus. Plantios de safrinha também expõem a cultura a condições climáticas distintas daquelas predominantes nos plantios de verão, o que pode determinar a alta incidência e severidade de doenças no milho, quando as condições de temperatura, umidade relativa do ar e luminosidade são favoráveis ao desenvolvimento do agente causal e/ou de seu inseto vetor.

Entre as doenças economicamente importantes para o milho, no Brasil, incluem-se o enfezamento pálido, cujo agente causal é o Spiroplasma kunkelii, e o enfezamento vermelho, associado a um fitoplasma, ambos patógenos pertencentes à classe Mollicutes (Bascopé \& Galindo, 1980; Whitcomb, 1986), transmitidos pela cigarrinha Dalbulus maidis (Nault, 1980; Oliveira et al., 2002).
Os dois tipos de enfezamentos podem ser diferenciados com base em sintomas, porém, freqüentemente essa distinção é limitada, dependendo da cultivar e da idade em que a planta foi infectada (Nault, 1980; Fernandes \& Oliveira, 1997). Os molicutes podem ser detectados nos tecidos de plantas de milho infectadas, por testes de PCR (Lee et al., 1993; Harrison, 1996; Barros et al., 2001).

Apenas o Maize Rayado Fino Virus (MRFV), o Maize Mosaic Virus e o Maize Dwarf Mosaic Virus, respectivamente, transmitidos pela cigarrinha $D$. maidis, pela cigarrinha Peregrinus maidis e por pulgões, estão relatados em milho, no Brasil, embora essa cultura possa ser infectada por muitos vírus distintos, em diversos países no mundo (Kitajima et al., 1976; Shurtleff, 1980; Almeida et al., 2000).

Neste trabalho avaliou-se a incidência de enfezamentos e de viroses em milho em plantios de safrinha e da safra de verão e verificou-se a predominância entre fitoplasma e espiroplasma nessas épocas de plantio.

\section{Material e Métodos}

Para avaliações da incidência de enfezamentos e de viroses, um ensaio com 22 cultivares de milho foi plantado em diferentes locais, nos Estados de São Paulo, Goiás e Minas Gerais, nas épocas de 
plantio do milho safrinha e da safra de verão, com início no período da safrinha de 1999 e término no período da safrinha de 2001 (Tabela 1). As parcelas experimentais foram constituídas por uma fileira de $5 \mathrm{~m}$ para cada cultivar, com três repetições, em delineamento de blocos ao acaso. As avaliações da incidência de enfezamentos e de viroses foram feitas na época do enchimento de grãos. As 22 cultivares de milho utilizadas no ensaio foram previamente escolhidas com base em informações fornecidas por empresas produtoras de sementes e em observações isoladas, feitas anteriormente em campo, referentes ao comportamento de cada uma quanto à resistência aos enfezamentos, sendo algumas consideradas altamente suscetíveis, outras altamente resistentes, e outras intermediárias. Foram consideradas altamente suscetíveis cultivares anteriormente observadas com índices da ordem de $100 \%$ das plantas apresentando sintomas de enfezamentos. Foram consideradas cultivares altamente resistentes aquelas freqüentemente observadas sem sintomas dessas doenças, quando cultivadas simultaneamente com outras apresentando índices elevados de plantas com sintomas.

As determinações do percentual de plantas com sintomas de enfezamentos e de viroses foram sempre realizadas em uma cultivar considerada altamente suscetível à infecção por molicutes. Apenas uma cultivar considerada altamente resistente à infecção por esses patógenos foi sempre avaliada para confirmação da ausência de sintomas de enfezamentos. Foram considerados sintomas de enfezamentos a presença de folhas avermelhadas, principalmente nas margens e/ou nas extremidades, a presença de estrias esbranquiçadas iniciando-se na base das folhas, típicas da infecção por espiroplasma, associadas ou não à proliferação de espigas e/ou redução na altura da planta, sem distinção entre o enfezamento pálido e o enfezamento vermelho.

Os níveis de incidência de enfezamentos e de viroses, em cada ensaio, foram obtidos pela média de incidência nas três repetições. A incidência média na safrinha e na safra de verão foi calculada pela média de incidência em todos os ensaios avaliados nos diversos locais e nessas épocas. A incidência nos estados de São Paulo e de Goiás foi calculada pela média dos ensaios conduzidos em cada um. No estado de Minas Gerais, foi representada pela média do ensaio conduzido em Sete Lagoas, considerando-se sempre as duas épocas de plantio.

TABELA 1. Localidades e épocas de avaliação da incidência de enfezamentos e de viroses em ensaio com 22 cultivares de milho.

\begin{tabular}{llllll}
\hline Estado & Sfr 1999 & Sfv 1999/2000 & Sfr 2000 & Sfv 2000/2001 & Sfr 2001 \\
\hline \multirow{2}{*}{ São Paulo } & Assis & Assis & Assis & Assis & Assis \\
& Capão Bonito & Capão Bonito & Capão Bonito & Capão Bonito & Capão Bonito \\
& Jardinópolis & Jardinópolis & - & Jardinópolis & Jardinópolis \\
\hline \multirow{2}{*}{ Goiás } & Vicentinópolis & Vicentinópolis & - & - & - \\
& Santa Helena de Goiás & Santa Helena de Goiás & Santa Helena de Goiás & Santa Helena de Goiás & - \\
& - & Montividiu & - & Montividiu & Montividiu \\
\hline Minas Gerais & Sete Lagoas & Sete Lagoas & Sete Lagoas & Sete Lagoas & Rio Verde \\
\hline
\end{tabular}

(-) Não avaliado; Sfr - Safrinha; Sfv - Safra de Verão. 
Todas as cultivares foram avaliadas também para verificar a incidência de possíveis novos vírus, para comparação de sintomas de enfezamentos e para coleta de amostras para detecção desses patógenos.

Em cada ensaio, nos diferentes locais e épocas de plantio, foram coletadas as folhas-bandeiras em 15 plantas, de cinco cultivares apresentando sintomas de enfezamentos, para detecção dos molicutes presentes. Essas amostras foram transportadas em caixa térmica com gelo, sendo liofilizadas ou mantidas em laboratório, congeladas, até a detecção dos molicutes. A extração do DNA foi conduzida segundo protocolo de Saghai-Maroof et al. (1984) modificado e a detecção de espiroplasma e de fitoplasma foi feita utilizando-se respectivamente, os seguintes pares de oligonucleotídeos: CSSF2: 5'GGC AAA AGA TGT AAC AAA AGT-3' e CSSR6: 5'-GTT ACT TCAACA GTA GTT GCG3' (Barros et al., 2001); e R16F2: 5'-ACG ACT GCT GCT AAG ACT GG-3' e R16R2: 5'-TGA CGG GCG GTG TGT ACA AAC CCC G-3' Lee et al. (1993). Foram utilizadas as condições de reação descritas por Lee et al. (1993) em PCR multiplex.

As amostras de folhas com sintomas de Maize Rayado Fino Virus e de Maize Dwarf Mosaic Virus foram coletadas apenas uma vez nos locais em que essas viroses foram detectadas. O RNA total das amostras de folha de milho foi extraído de acordo com Lane (1986), o RNA da preparação purificada foi extraído utilizando-se o método descrito por De Vries et al.(1982) e as amostras foram submetidas a análises de RT-PCR (Hammond et al., 1997; Almeida et al., 2000), para confirmação de infecção por esses vírus. Foram considerados sintomas de MRFV pontos cloróticos coalescentes nas folhas, com aspecto de riscos finos, sempre paralelos às nervuras secundárias. Plantas com sintomas foliares caracterizados por manchas cloróticas entremeadas por áreas verdes, em padrão de mosaico, foram consideradas infectadas por MDMV.

Os resultados obtidos em todas as avaliações foram submetidos a análises de distribuição de freqüência.

\section{Resultados e Discussão}

De forma geral, os níveis de incidência de enfezamentos foram mais altos nos plantios de safrinha, em relação aos plantios da safra de verão (Figura 1). Observou-se, contudo, que, no estado de São Paulo, essa incidência manteve-se igualmente elevada tanto na safrinha quanto na safra de verão (Tabela 2).

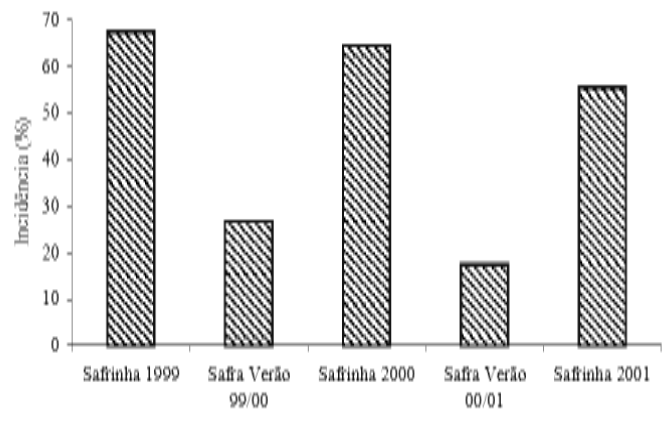

FIGURA 1. Incidência de plantas com sintomas de enfezamentos causados por molicutes em milho, na safrinha e na safra de verão (média dos ensaios).

TABELA 2. Incidência (\%) de plantas com sintomas de enfezamentos causados por molicutes em milho, na safrinha e na safra de verão, no período da safrinha de 1999 à safrinha de 2001 (média dos ensaios).

\begin{tabular}{lcc}
\hline Estados & Safrinha & Safra Verão \\
\hline São Paulo & 58,6 & 47,7 \\
Goiás & 54,5 & 6,6 \\
Minas Gerais & 74,7 & 12,0 \\
\hline
\end{tabular}


A maior incidência de enfezamentos nos plantios de safrinha, em relação aos plantios da safra de verão, podem ser explicados com base em dois aspectos principais. A colheita da safra de verão, normalmente realizada nos primeiros meses do ano, pode favorecer a migração das cigarrinhas infectivas com molicutes, das lavouras em final de ciclo para as plantas jovens do milho safrinha, uma vez que os plantios de safrinha são, geralmente, realizados nos meses de fevereiro e março. Aparentemente, em lavouras no final do ciclo, ocorrem picos populacionais de cigarrinhas infectivas com molicutes, visto que, geralmente, quando as plantas de milho são infectadas nos estádios iniciais de desenvolvimento, esses patógenos podem ser detectados nas folhas-bandeiras dessas plantas, quando estas se encontram na fase de enchimento de grãos (Oliveira et al., 2001). Por outro lado, os plantios de safrinha, nos meses de fevereiro e março, coincidem com as chuvas de verão, que podem proporcionar maior umidade relativa do ar. Entre os fatores que favorecem a alta incidência dessas doenças na cultura do milho, Oliveira \& Oliveira (2001) verificaram correlação direta entre a umidade relativa do ar e a incidência de enfezamentos.

Da mesma forma, pode-se explicar a paridade de distribuição dos enfezamentos na safrinha e na safra de verão, no estado de São Paulo. Por um lado, esse estado planta mais milho safrinha que os estados de Goiás e de Minas Gerais e, provavelmente, a variação nas datas de plantio das diversas lavouras, com sobreposição dos ciclos da cultura, contribui para a multiplicação dos molicutes e de seu inseto vetor, a cigarrinha $D$. maidis. Nesse caso, as lavouras de milho no estado de São Paulo estariam sujeitas a maior pressão de inóculo desses patógenos que nos outros locais avaliados. A perpetuação dos enfezamentos em plantios consecutivos de milho com sobreposição dos ciclos da cultura foi recentemente demonstrada por Oliveira \& Oliveira, (2001). As condições ambientais do estado de São Paulo podem ser mais favoráveis à alta incidência de enfezamentos tanto na safrinha quanto na safra de verão, em relação a Goiás e Minas Gerais.

Dentre o total de 390 amostras coletadas nos diferentes locais e épocas de plantio, em plantas com sintomas de enfezamentos e submetidas ao teste de PCR multiplex (Figura 2), a presença de molicutes foi confirmada em apenas $26,4 \%$, correspondente a 103 amostras positivas (número de plantas com presença de espiroplasma e/ou fitoplasma detectada por PCR) e 109 detecções (número de vezes em que constatou-se a presença de espiroplasma ou de fitoplasma, nas 103 amostras positivas). Em apenas seis amostras (correspondente a 5,8\%), dentre as 103 amostras positivas, foi constatada a infecção simultânea por espiroplasma e por fitoplasma. Limitações na detecção desses patógenos em amostras coletadas em campo têm sido atribuídas à sua distribuição desuniforme nas plantas (Oliveira et al., 1998), possivelmente dependente da idade em que a planta foi infectada, devendo-se considerar também a idade do tecido amostrado e a qualidade do DNA extraído.

Independentemente da época e do local de plantio, a presença de fitoplasma e de espiroplasma foi confirmada em $47,2 \%$ e em $53,2 \%$ das amostras positivas, respectivamente, evidenciando que os dois patógenos devem ser considerados importantes quanto à incidência na cultura do milho.

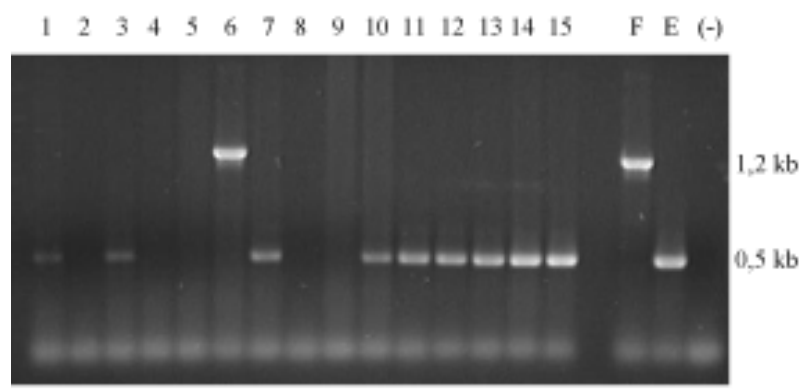

FIGURA 2. Resultado do PCR multiplex para detecção simultânea de espiroplasma e de fitoplasma em 15 amostras de folhas de milho coletadas em Rio Verde, GO. F = fitoplasma $(1,2 \mathrm{~kb}), \mathrm{E}=$ espiroplasma $(0,5 \mathrm{~kb}) \mathrm{e}(-)=$ controle negativo. 
A distribuição de freqüência das 109 detecções de fitoplasma e/ou de espiroplasma, em função das épocas de plantio, mostrou que, nas safras de verão, o nível de incidência desses patógenos foi semelhante; porém, em cada época de safrinha, predominou um dos dois (Figura 3). É provável que a predominância de um ou de outro desses molicutes tenha sido determinada pela temperatura ambiente. Em cultura axênica, o espiroplasma tem sido cultivado em temperaturas em torno de $30^{\circ} \mathrm{C}$. Além disso, já foi demonstrado que temperaturas em torno de $31^{\circ} \mathrm{C}$ durante o dia e $25^{\circ} \mathrm{C}$ durante a noite aceleram o desenvolvimento desse patógeno nas plantas de milho e no inseto vetor (Nault, 1980). Portanto, é provável que altas temperaturas possam favorecer prioritariamente o desenvolvimento do espiroplasma, em detrimento do fitoplasma, e que em baixas temperaturas o espiroplasma não se multiplique bem, permitindo a predominância do fitoplasma. Possivelmente, essa hipótese pode também ser considerada para explicar porque, dentre as 103 amostras positivas para a detecção de molicutes, 94,5\% estavam infectadas apenas por espiroplasma ou por fitoplasma. Cigarrinhas que se desenvolveram sob determinadas condições de temperatura poderiam ser portadoras de apenas um desses patógenos, para infecção dessas plantas.

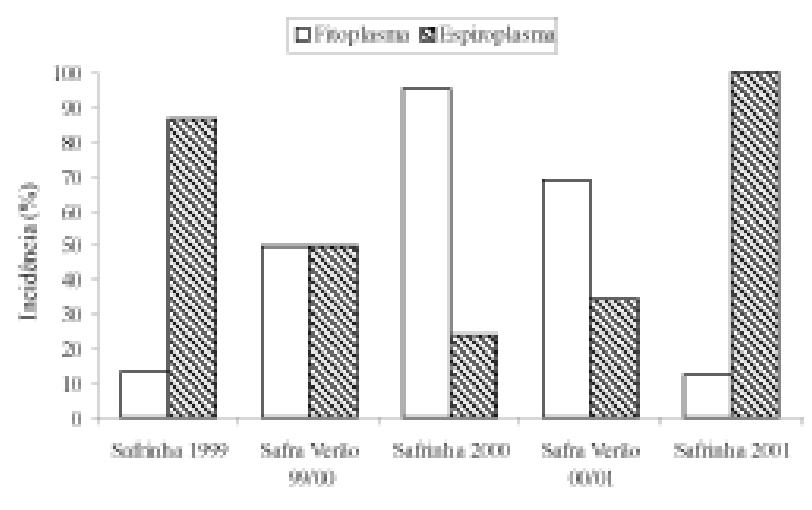

FIGURA 3. Incidência de molicutes na safrinha e na safra de verão (média dos ensaios).
Observa-se, ainda, que as temperaturas de outono, período coincidente com parte do desenvolvimento de lavouras de milho plantadas na safrinha, foram mais baixas no ano de 2000 que em 2001, o que pode ter limitado o desenvolvimento do espiroplasma, com conseqüente aumento na incidência do fitoplasma na safrinha de 2000 (Figura 3). Em levantamento realizado no estado do Paraná, também foi constatada a predominância de fitoplasma (Oliveira et al. 2001), confirmando os resultados obtidos neste trabalho.

A distribuição de freqüência das 109 detecções de fitoplasma e de espiroplasma em função das altitudes médias dos vários municípios em que foram conduzidos os ensaios não mostrou diferenças acentuadas, embora $72,4 \%$ das amostras infectadas por espiroplasma tenham se concentrado nos municípios com altitudes inferiores a $650 \mathrm{~m}$ (Figura 4). Considera-se possível, entretanto, que essa ocorrência de espiroplasma mais concentrada em municípios de baixa altitude possa estar antes associada a temperaturas mais elevadas nesses locais que ao efeito direto da altitude, porém, essa variável não foi controlada durante a condução dos ensaios.

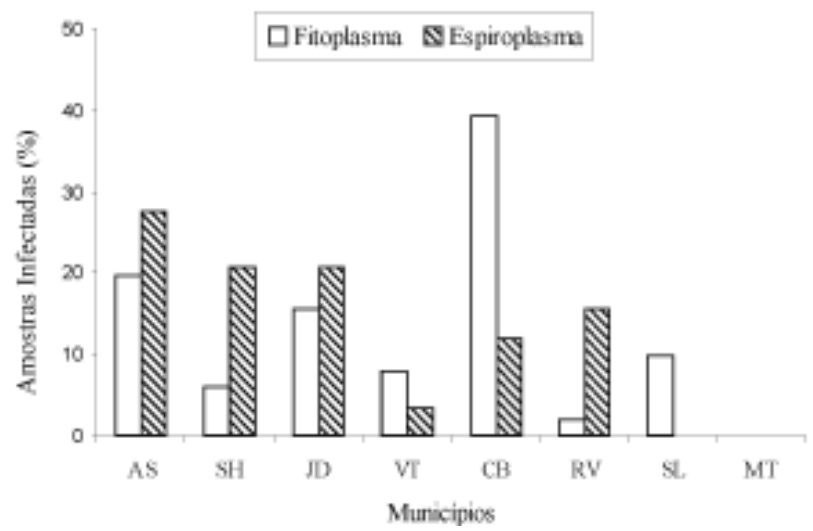

FIGURA 4. Incidência de molicutes em municípios com diferentes altitudes. AS = Assis, SP (546 m); $\mathrm{SH}=$ Santa Helena de Goiás, GO (562 m); JD = Jardinópolis, SP (590 m); VT = Vicentinópolis, GO (646 m); CB = Capão Bonito, SP (705 m); RV = Rio Verde, GO (715 m); SL = Sete Lagoas, MG (761 m); MT = Montividiu, GO (821 m). 
Foi observado também nesses ensaios que, quando infectadas por molicutes, algumas cultivares apresentaram maior grau de avermelhamento que outras. A cultivar previamente considerada com alto nível de resistência não apresentou sintomas de enfezamentos na maioria dos locais e épocas avaliadas, excetuando-se na safrinha de 2001, no município de Rio Verde (GO), em que apresentou 57,6\% das plantas com sintomas. Esse resultado sugere a existência de variantes genéticos dos molicutes, que podem quebrar a resistência de cultivares.

Não foram detectados novos vírus ocorrendo em qualquer das cultivares incluídas no ensaio, nos diversos locais e épocas de plantio avaliados. Apenas o MRFV e o MDMV foram detectados, em geral, em baixa incidência, e com grande variação entre os municípios e épocas amostradas (Tabela 3); a identidade desses vírus foi confirmada através das análises por RT-PCR. Os níveis de incidência desses vírus podem ser variáveis em anos distintos, sendo dependentes sempre da presença das cigarrinhas e dos afídeos e de fontes de inóculo nas proximidades das lavouras de milho, além de serem influenciados por condições climáticas (Almeida et al., 2001; Oliveira \& Oliveira, 2001).

De forma geral, os resultados obtidos evidenciaram maior incidência dos enfezamentos causados por molicutes na cultura do milho, em relação às viroses, e sugerem limitações quanto à possibilidade de escape a essas doenças através da escolha do local e da época de plantio.

TABELA 3. Incidência de plantas (\%) com sintomas de infecção por vírus, na safrinha e na safra de verão, nos municípios amostrados.

\begin{tabular}{|c|c|c|c|c|c|c|}
\hline Municipios & & Sfr 1999 & Sfv $99 / 00$ & Sfr 2000 & Sfv $00 / 01$ & Sfr 2001 \\
\hline \multirow[t]{2}{*}{ Capão Bonito (SP) } & MRFV & 0,0 & 0,0 & 12,2 & 0,0 & 1,0 \\
\hline & MDMV & 0,0 & 0,0 & 0,0 & 0,0 & 0,0 \\
\hline \multirow{2}{*}{ Assis (SP) } & MRFV & 0,0 & 16,7 & 0,0 & 2,7 & 5,8 \\
\hline & MDMV & 0,0 & 0,0 & 0,0 & 0,0 & 0,0 \\
\hline \multirow[t]{2}{*}{ Jardinópolis (SP) } & MRFV & 0,0 & 6,0 & - & 1,5 & 8,1 \\
\hline & MDMV & 20,2 & 0,0 & $\cdot$ & 0,0 & 0,0 \\
\hline \multirow[t]{2}{*}{ Santa Helena de Goiás (GO) } & MRFV & 0,0 & 0,0 & 0,0 & 4,3 & - \\
\hline & MDMV & 29,2 & 0,0 & 23,3 & 5,8 & - \\
\hline \multirow[t]{2}{*}{ Montividiu (GO) } & MRFV & - & 0,0 & - & 0,0 & 11,4 \\
\hline & MDMV & - & 0,0 & - & 0,0 & 8,0 \\
\hline \multirow{2}{*}{ Vicentinópolis (GO) } & MRFV & 0,0 & 0,0 & - & - & - \\
\hline & MDMV & 0,0 & 0,0 & - & - & - \\
\hline \multirow[t]{2}{*}{ Rio Verde (GO) } & MRFV & - & - & - & - & 10,3 \\
\hline & MDMV & - & - & - & - & 0,0 \\
\hline \multirow[t]{2}{*}{ Sete Lagoas (MG) } & MRFV & 0,0 & 0,0 & 34,3 & 0,0 & 0,0 \\
\hline & MDMV & 0,0 & 0,0 & 0,0 & 0,0 & 0,0 \\
\hline
\end{tabular}

(-) Não avaliado; Sfr - Safrinha; Sfv - Safra de Verão. 


\section{Conclusões}

1- Em geral, os níveis de incidência de enfezamentos causados por molicutes são mais elevados nos plantios de safrinha, em relação aos plantios da safra de verão.

2-Em geral, os níveis de incidência de fitoplasma e de espiroplasma nos plantios da safra de verão tendem a ser semelhantes, porém, pode ocorrer predominância de fitoplasma ou de espiroplasma nos plantios de safrinha, em anos distintos.

3- Atualmente, a incidência de enfezamentos é maior que a incidência de viroses na cultura do milho, nas regiões estudadas.

\section{Agradecimentos}

À Sementes Dow AgroScience, à Monsanto, ao Instituto Agronômico e ao Centro de Desenvolvimento do Vale do Paranapanema o auxílio na condução dos ensaios em campo.

\section{Literatura Citada}

ALMEIDA, A.C.L.; OLIVEIRA, E.; RESENDE, R.O. Detecção de vírus por RT-PCR, hibridização 'dot-blot" e dot-ELISA em milho. Fitopatologia Brasileira, Brasília, v.25, n.2, p.168-174, 2000.

ALMEIDA, A.C.L.; OLIVEIRA, E.; RESENDE, R.O. Fatores relacionados à incidência e disseminação do vírus do mosaico comum do milho. Fitopatologia Brasileira, Brasília, v.26, n.4, p.766769, 2001.

BARROS, T.S.L.; DAVIS, R.E.; RESENDE, R. O. Design of a polymerase chain reaction for specific detection of corn stunt spiroplasma, Spiroplasma kunkelii. Plant Disease, St. Paul, v. 85, p.475480, 2001.

BASCOPÉ, Q.B.; GALINDO A. J. Naturaleza micoplásmica de la raza "mesa central" del achaparramiento del maíz. Revista Fitopatologia, Lima, v. 16, n. 1, p. 28-33, 1980.
CONAB. Consolidação do plantio safra agrícola 2001/2002 - Segundo Levantamento. Brasília, 2001.

De VRIES, S.C.; SPRINGER, J.; WESSELS, J. G. H. Diversity of abundant mRNA sequences and patterns of proteins synthesis in etiolated and greened pea seedlings. Planta, Berlin, v. 156, p. 129-135, 1982.

FERNANDES, F. T.; OLIVEIRA, E. Principais Doenças na Cultura de Milho. Sete Lagoas: EMBRAPA-CNPMS, 19957.80 p. (EMBRAPACNPMS. Circular Técnica, 26).

HARRISON, N. A.; RICHARDSON, P. A.; TSAI, J.H. PCR assay for detection of the phytoplasma associated with maize bushy stunt disease. Plant Disease, St. Paul, v.80, n.3, p.263-269, 1996.

HAMMOND, R. W.; KOGEL, R.; RAMIREZ, P. Variability of geographically distinct isolates of maize rayado fino virus in Latin America. Journal of General Virology, Cambridge, v. 78, p. 3153-3159. 1997.

KITAJIMA, E.W.; YANO, T.; COSTA, A.S. Purification and intracellular localization of isometric viruslike particles associated with Brasilian corn streak virus infection. Ciência e Cultura, São Paulo, v.28, n.4, p.427-431, 1976.

LANE, L.C. Propagation and purification of RNA plant viruses. Methods in Enzimology, San Diego, v. 20, p. 687-696, 1986.

LEE, I.M.; HAMMONS, R.W.; DAVIS, R.E.; GUNDERSEN, D.E. Universal amplification and analysis of pathogen $16 \mathrm{~S}$ rDNA for classification and indentification of mycoplasmalike organisms. Phytopathology, St. Paul, v.83, n.8, p.834-842, 1993. 
NAULT, L.R. Maize bushy stunt and corn stunt: a comparison of disease symptoms, pathogen host ranges, and vectors. Phytopathology, St. Paul, v.70, p.659-662, 1980.

OLIVEIRA, E.; OLIVEIRA, A.C. Incidência de Enfezamentos e de Maize Rayado Fino Virus em milho em diferentes épocas de plantio e efeitos da expressão de sintomas foliares na produção. Fitopatologia Brasileira, Brasília, v.26, p.510, 2001. Suplemento.

OLIVEIRA, E.; RESENDE, R..O.; GIMENEZ PECCI, M.P.; LAGUNA, I.G.; HERRERA, P.; CRUZ, I. Doenças causadas por molicutes e por vírus na cultura do milho safrinha no Paraná. Fitopatologia Brasileira, Brasília, v.26, p.509, 2001. Suplemento.

OLIVEIRA, E.; WAQUIL, J.M; FERNANDES, F.T.; PAIVA, E; RESENDE, R.O.; KITAJIMA, W.E. Enfezamento pálido e enfezamento vermelho na cultura do milho no Brasil Central. Fitopatologia Brasileira, Brasília, v.23, n.1, p.45-47,1998.
OLIVEIRA, C.M; MOLINA, R.M.S.; ALBRES, R.S; LOPES, J.R.S. Disseminação de molicutes do milho a longas distâncias por Dalbulus maidis (Hemiptera: Cicadellidae). Fitopatologia Brasileira, Brasília, v.27, n.1, p.91-95, 2002.

SAGHAI MAROOF, M.A.; SOLIMAN, K.M.; JORGENSEN, R.A.; ALLARD, R.W. Ribosomal DNA spacer-length polymorphisms in barley, Mendelian inheritance, chromosomal location, and population dynamics. Proceedings of the National Academy of Science, Washington, v. 81, p. 80148018, 1984.

SHURTLEFF, M. C. (Ed.). Compendium of corn diseases 2. ed. St. Paul: APS Press, 1980. 105p.

WHITCOMB, R.F.; CHEN, T.A.; WILLIAMSON, D.L.; LIAO, C.; TULLY, J.G.; BOVÉ, J.M.; MOUCHES, C.; ROSE, D.L.; COAN, M.E.; CLARK, T.B. Spiroplasma kunkelii sp. nov.: Characterization of the etiological agent of corn stunt disease. International Journal of Systematic Bacteriology, Washington, v.36 n.2, p. $170-178,1986$ 